Review

\title{
Usutu Virus: An Emerging Flavivirus in Europe
}

\author{
Usama Ashraf ${ }^{1,2,3}$, Jing Ye ${ }^{1,2,3}$, Xindi Ruan ${ }^{1,2,3}$, Shengfeng Wan ${ }^{1,2,3}$, Bibo Zhu ${ }^{1,2,3}$ \\ and Shengbo Cao $1,2,3, *$
}

1 State Key Laboratory of Agricultural Microbiology, Huazhong Agricultural University, Wuhan, Hubei 430070, China; E-Mails: usamaashraf1523@gmail.com (U.A.); yeah_zaizai@hotmail.com (J.Y.); 258390599@qq.com (X.R.); wansf126@126.com (S.W.); zhubibohzau@126.com (B.Z.)

2 Laboratory of Animal Virology, College of Veterinary Medicine, Huazhong Agricultural University, Wuhan, Hubei 430070, China

3 Laboratory of development of Veterinary Diagnostic Products, Ministry of Agriculture, College of Veterinary Medicine, Huazhong Agricultural University, Wuhan, Hubei 430070, China

* Author to whom correspondence should be addressed; E-Mail: sbcao@mail.hzau.edu.cn; Tel./Fax: +86-278-728-2608.

Academic Editor: Karyn Johnson

Received: 11 November 2014 / Accepted: 13 January 2015 / Published: 19 January 2015

\begin{abstract}
Usutu virus (USUV) is an African mosquito-borne flavivirus belonging to the Japanese encephalitis virus serocomplex. USUV is closely related to Murray Valley encephalitis virus, Japanese encephalitis virus, and West Nile virus. USUV was discovered in South Africa in 1959. In Europe, the first true demonstration of circulation of USUV was reported in Austria in 2001 with a significant die-off of Eurasian blackbirds. In the subsequent years, USUV expanded to neighboring countries, including Italy, Germany, Spain, Hungary, Switzerland, Poland, England, Czech Republic, Greece, and Belgium, where it caused unusual mortality in birds. In 2009, the first two human cases of USUV infection in Europe have been reported in Italy, causing meningoencephalitis in immunocompromised patients. This review describes USUV in terms of its life cycle, USUV surveillance from Africa to Europe, human cases, its cellular tropism and pathogenesis, its genetic relationship with other flaviviruses, genetic diversity among USUV strains, its diagnosis, and a discussion of the potential future threat to Asian countries.
\end{abstract}


Keywords: Usutu virus; SouthAfrica-1959; Austria; Culex pipiens; Turdus merula

\section{Introduction}

The genus Flavivirus of family Flaviviridae is composed of more than 70 viruses. Among them, Japanese encephalitis virus (JEV), West Nile virus (WNV), Murray Valley encephalitis virus (MVEV), dengue virus (DENV), St. Louis encephalitis virus, and yellow fever virus are important threats to human health [1-3]. Usutu virus (USUV) is a mosquito-borne flavivirus belonging to the JEV serocomplex [2,4] and thus is closely related to JEV, MVEV, and WNV [4]. In 1959, USUV was isolated from Culex neavei mosquitoes in South Africa, and this strain, SouthAfrica-1959, is now considered as the reference strain [5]. Later, USUV was found to be associated with fever and rash in an African man [6]. In Europe, the first emergence of USUV was reported in Austria in 2001 [7]; however, retrospective analysis of archived tissue samples from bird deaths in the Tuscany region of Italy in 1996 [8] proved a much earlier introduction of USUV into Europe than previously assumed [9]. In the subsequent years, USUV was found to circulate in several other European countries by mosquitoes displacement or infected birds [10,11]. In comparison to the human USUV case in Africa, the human cases in Europe were more serious with typical flavivirus-related neuroinvasiveness and neurovirulence [12,13].

This review focuses on aspects of USUV related to its emergence from Africa and spread to Europe, as well as genetic diversity among different USUV strains.

\section{Life Cycle of USUV}

The life cycle of USUV is quite similar to that of other members of the JEV serocomplex. Its natural life cycle involves mosquito-bird-mosquito cycles, in which mosquitoes act as vectors and birds as amplifying hosts. Many studies have demonstrated that multiple mosquito and avian species are involved in perpetuating the USUV life cycle [10,11]. Mosquitoes facilitate viral transmission to humans, horses, and rodents, which then act as incidental hosts [6,12-14]. Recently, USUV has also been isolated from bats in Germany [15]. The detection of USUV in bats raised questions for future research, including the potential role of bats as reservoirs in Africa and transmission by mosquito vectors.

USUV has been isolated from numerous mosquito species that include Culex pipiens [16-21], Cx. neavei [5], Culex perexiguus [10], Aedes albopictus [16], Aedes caspius, Anopheles maculipennis [19], Culex perfuscus, Coquillettidia aurites, and Mansonia Africana [22,23]. Of these, Cx. pipiens is considered to be the most common vector [16-21]. In addition, $C x$. neavei is the only mosquito species whose vector competence for USUV is known [24]; therefore, vector competence studies involving other mosquito species should be done to confirm their vector status.

Among avian species, Eurasian blackbirds (Turdus merula) showed the highest mortality owing to USUV infection [18,19,25-28]. Table 1 lists the diseased and non-diseased avian species with documented USUV infections along with their native geographic locations. USUV infection in the listed avian species was determined by immunohistochemistry, reverse transcription-PCR, indirect immunofluorescence assay, ELISA, and plaque reduction neutralization assay [18,19,25-28]. 
Table 1. Avian species infected with USUV in Europe.

\begin{tabular}{|c|c|c|c|}
\hline Species & Common Name & Country (year) & References \\
\hline $\begin{array}{c}\text { Dendrocopos major } \\
\text { Pyrrhula pyrrhula }\end{array}$ & $\begin{array}{c}\text { Great spotted woodpecker } \\
\text { Bullfinch } \\
\end{array}$ & Belgium (2014) & [29] \\
\hline Columba livia domestica & Domestic pigeon & Greece (2014) & {$[30]$} \\
\hline Turdus philomelos & Song thrushes & Spain (2012) & [31] \\
\hline Turdus merula & Eurasian blackbird & $\begin{array}{c}\text { Italy (2010-2011) } \\
\text { Germany (2011) } \\
\text { Hungary (2003-2006) } \\
\text { Austria (2001-2005) }\end{array}$ & {$[18,19,25-28]$} \\
\hline $\begin{array}{c}\text { Alcedo atthis } \\
\text { Serinus canaria domestica }\end{array}$ & $\begin{array}{c}\text { Common kingfisher } \\
\text { Canary }\end{array}$ & Germany (2011) & {$[26]$} \\
\hline $\begin{array}{c}\text { Alectoris rufa } \\
\text { Asio otus } \\
\text { Caprimulgus europaeus } \\
\text { Garrulus glandarius } \\
\text { Larus michahellis } \\
\text { Pica pica } \\
\text { Streptopelica decaocto }\end{array}$ & $\begin{array}{c}\text { Partridge } \\
\text { Long-eared owl } \\
\text { Nightjar } \\
\text { Eurasian jay } \\
\text { Yellow-legged gull } \\
\text { Eurasian magpie } \\
\text { Eurasian collared dove }\end{array}$ & Italy (2010-2011) & {$[18,19]$} \\
\hline $\begin{array}{c}\text { Ardea cinerea } \\
\text { Merops apiaster } \\
\text { Passer domesticus } \\
\text { Picus viridis } \\
\text { Sturnus vulgaris }\end{array}$ & $\begin{array}{c}\text { Grey heron } \\
\text { Eurasian bee-eater } \\
\text { House sparrow } \\
\text { Eurasian green woodpecker } \\
\text { Common starling }\end{array}$ & $\begin{array}{l}\text { Germany (2011) } \\
\text { Italy (2010-2011) }\end{array}$ & {$[18,19,26]$} \\
\hline Strix nebulosa & Great grey owl & $\begin{array}{c}\text { Germany (2011) } \\
\text { Austria (2001-2002) }\end{array}$ & {$[26,27]$} \\
\hline Gallus gallus domesticus & Chicken & $\begin{array}{c}\text { Italy (2007-2009) } \\
\text { Switzerland (2006-2007) } \\
\text { England (2006) }\end{array}$ & {$[14,32-34]$} \\
\hline $\begin{array}{l}\text { Spheniscus humboldti } \\
\text { Phoenicopterus ruber } \\
\text { Dacelo novaeguineae }\end{array}$ & $\begin{array}{l}\text { Humboldt penguin } \\
\text { Greater flamingo } \\
\text { Laughing kookaburra }\end{array}$ & Switzerland (2006-2007) & {$[34]$} \\
\hline $\begin{array}{c}\text { Ciconia ciconia } \\
\text { Leptoptilos crumeriiferus } \\
\text { Neophron percnopterus } \\
\text { Bubo bubo } \\
\text { Bubo scandiacus } \\
\text { Strix uralensis }\end{array}$ & $\begin{array}{c}\text { White stork } \\
\text { Marabou stork } \\
\text { Egyptian vulture } \\
\text { Eurasian eagle owl } \\
\text { Snowy owl } \\
\text { Ural owl }\end{array}$ & Austria (2006-2007) & {$[34]$} \\
\hline
\end{tabular}

\section{USUV Surveillance from Africa to Europe}

Following its identification in South Africa in 1959, USUV was reported in other African countries, including Central African Republic in 1969 (CAR-1969) and 1981 (CAR-1981), in Senegal in 1974 (Kedougou-1974), 1993 (Barkedji-1993), and 2007 (Barkedji-2007) [6,22,35,36], and in Tunisia in 2014 [37]. Since its introduction to Africa, it had typically been isolated from mosquitoes and had never been associated with serious illness in mammals. It had been isolated from mammals two times: the first 
instance was in an African furred rat (Praomys sp.), and the second instance was in a man (CAR-1981) who exhibited fever and rash [6]. It is not known whether USUV originated in Africa or was introduced into this continent. Therefore, it is essential to gain a better understanding of the geographical distribution, ecology, epidemiology, and genetic diversity of this virus in Africa.

In 2001, the emergence of USUV was confirmed in Europe after a considerable die-off of Eurasian blackbirds (T. merula) in Vienna, Austria [7]. In subsequent years, USUV was found in several other European countries, including Hungary (2003-2006) [25], Switzerland (2006) [11], Spain (2006-2009) [10,17], Italy (2009) [16,38], Germany (2013) [15], and Belgium (2014) [29], with virus isolation from mosquitoes, birds, and bats.

Moreover, USUV infection has also been demonstrated serologically in birds in England (2001-2004) [32], Czech Republic (2005) [39], Spain (2003-2006) [40], Poland (2006) [41], Switzerland (2006) [33], Germany (2007) [42], Italy (2007) [43], and Greece (2014) [30]. The recurrence of the virus in Italy (2010-2011) [18,19], Germany (2011) [26], Spain (2012) [31], and Czech Republic (2011-2012) [44] suggests persistence of the transmission cycle in the affected areas, possibly through overwintering mosquitoes [45]. In addition to wild birds, the prevalence of USUV has also been reported in birds of the zoological parks of Austria and Switzerland [34]. The broad immunological cross-reactivity between USUV and other flaviviruses could hamper the interpretation of results from serological-based studies on birds. Therefore, there is need for the development of standardized laboratory tests using validated methods that enable the differentiation of infections caused by USUV from those caused by antigenically related flaviviruses. The locations of the epidemiological studies confirming the presence of USUV in Europe are shown in Figure 1.

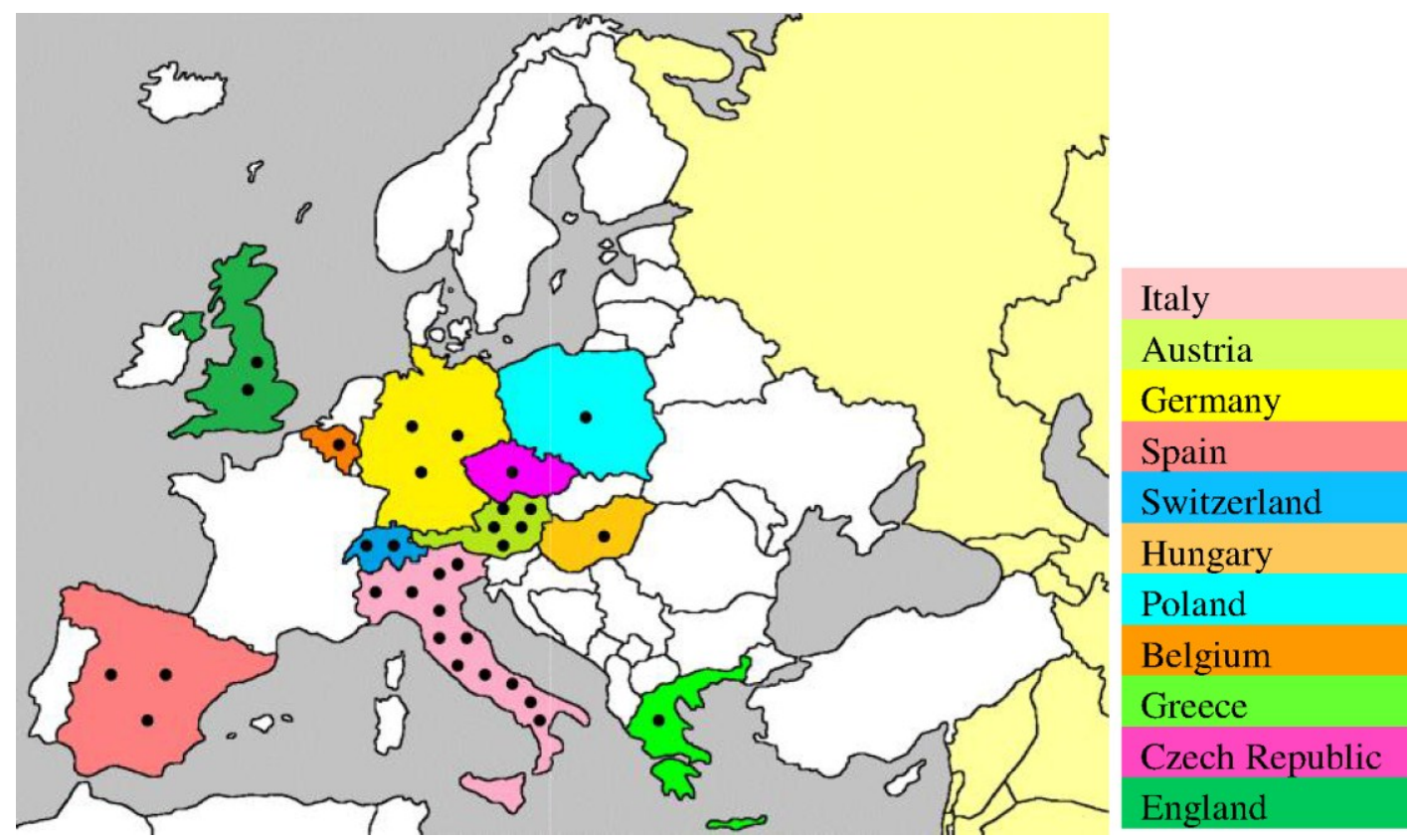

Figure 1. Geographic locations of USUV-related epidemiological studies on birds and mosquitoes in Europe. These studies were conducted using immunohistochemistry, reverse transcription-PCR, indirect immunofluorescence assay, ELISA, and plaque reduction neutralization assay [10,11,25,29-33,38-44]. Each epidemiological study is indicated by $\bullet$ 
Interestingly, similar blackbird deaths had also been reported in Italy in 1996 [8], as were in Austria in 2001 [7]. However, the virus responsible for those deaths was unknown at that time. Because this blackbird die-off event was only reported in a local Italian veterinary journal [8], it failed to get worldwide attention. In 2013, the partial nucleotide sequence of that unknown virus was compared with the Austrian strain (Vienna-2001), revealing complete sequence identity [9]. Based on these data, USUV emergence in Europe was much earlier than previously thought.

\section{USUV Infection in Humans}

In addition to avian species, USUV has also been detected in humans. As previously discussed, the first case affecting a human was reported in Central African Republic in 1981 in a man with fever and rash [6]. Later, this strain was sequenced completely and designated CAR-1981 [46]. However, the history of the first human case of USUV-related illness is not very old in Europe. In 2009, the first European case was reported in Italy in a woman suffering from meningoencephalitis [12]. The analysis of cerebrospinal fluid by heminested RT-PCR assay that targets the prM and NS5 genes of flaviviruses, proved it a flavivirus infection. The nucleotide sequence of the yielded amplicon showed $98 \%$ identity to both Austrian (Vienna-2001) and Hungarian (Budapest-2005) strains and, thus, revealed the first human case of USUV-related neuroinvasive illness in Europe [12]. In addition, in 2009, USUV was isolated in Vero E6 cells from the blood of another Italian female patient who had undergone orthotropic liver transplantation [13]. This USUV-related viremia was confirmed by heminested RT-PCR assay targeting the NS5 gene of flaviviruses and subsequent identification by sequencing, which showed $98 \%$ identity to the USUV genome sequences available in GenBank [13]. This strain was sequenced completely and designated Bologna-2009 [47].

In 2012, a serological surveillance program was conducted in humans in southwest Germany [48]. A total of 4200 human serum samples were analyzed by an immunofluorescence assay for the detection of antibodies reacting with USUV antigen. All samples that were positive by this assay were double-checked by a commercially available USUV-specific IgG-capture ELISA kit. Among them, only one sample showed neutralizing antibodies against USUV, indicating a low and asymptomatic prevalence of USUV in Germany. A similar asymptomatic prevalence was reported in Italy, where four of 359 healthy blood donors tested positive for USUV-specific antibodies [49]. In 2013, neutralizing antibodies against USUV have also been detected in three patients in Croatia, suspected with WNV-related neuroinvasive infection [50].

Further studies should be implemented to assess the real risk of USUV infection in humans and to establish the usefulness of bird surveillance as a predictive marker for a USUV outbreak in humans.

\section{Cellular Tropism and Pathogenesis of USUV}

USUV can infect cells of various tissues types derived from humans and a wide variety of animal species [51]. Bakonyi et al. investigated the susceptibility of various cell lines and cultures to USUV infection that include HeLa (human), Vero (simian), ED (equine), PK-15 (porcine), RK-13 (lapin), MDBK (bovine), MDCK (canine), DK (canine), CR (feline), BHK-21 (hamster), BF (hamster), C6 (rat), TH1 (turtle), primary goose embryo fibroblasts, and horse kidney cells [51]. Among them, Vero, PK-15, and goose embryo fibroblast cells developed cytopathic effects, indicating the suitability of these cells 
for diagnostic purposes. However, viral multiplication was detected in all mammalian cells by immunohistochemistry [51]. This difference in pathogenesis might have been influenced by several factors, including the role of defective interfering particles, immune response, and host resistance genes [52]. USUV has also been detected in brain, heart, liver, kidney, lungs, and intestinal tissues of laboratory infected mice [53] and natural infected birds [54], and this tissue tropism is similar to WNV [55]. However, demyelination of infected neurons was found to be a unique feature of USUV infection [53]. Further investigations involving different mammalian species will be important to estimate possible threat to domesticated animals and human population.

Autophagy is an important cellular pathway that contributes important roles in viral infections and pathogenesis [56]. In relation to genus Flavivirus, autophagy has been associated with multiple aspects of replication and pathogenicity of some members of this genus, including DENV [57], JEV [58], and USUV [59]. Some viruses, including USUV, can take advantage of autophagic process by incorporating the components from this cellular pathway in their own replication $[59,60]$. Upon USUV infection, the unfolded protein response due to Xbp-1 mRNA splicing and cytoplasmic aggregation of lipidated form of microtubule-associated protein 1 light chain 3 have been observed [59], which are considered as markers of autophagosome formation during viral infections [61]. Treatment with rapamycin, an inductor of autophagy, resulted in an increase in viral titer, whereas modulation of this pathway with inhibitors, wortmannin or 3-methyladenine resulted in a decrease in viral titer [59]. These findings provide the basis for the design of new antiviral therapies against USUV.

\section{Genomic Structure and Phylogenetic Analysis of USUV}

USUV is a small, spherical, enveloped virus with a diameter of 40-60 nm [62]. It has an 11-kb positive-sense, single-stranded RNA genome with a 5' cap, but without a 3' poly-A tail [62]. Similar to other flaviviruses, the genome contains a unique open reading frame spanning nucleotides 97-10,401. The USUV open reading frame encodes a polyprotein precursor of 3434 amino acid residues, which undergoes proteolytic cleavage by both viral and cellular proteases to yield three structural and eight non-structural (NS) proteins (Figure 2). The structural proteins - core (C), pre-membrane (prM), and envelope (E) - contribute to the viral structural elements, whereas the NS proteins NS1, NS2A, NS2B, NS3, NS4A, 2K, NS4B, and NS5, regulate viral replication [62].

Phylogenetic analyses have been used to explore the genetic relationship among flaviviruses. In 2004, a phylogeny of the genus Flavivirus was established including one African (SouthAfrica-1959) and one European (Vienna-2001) strain of USUV [62]. This study was carried out by conducting both complete genome as well as polyprotein precursor sequence analyses [62] rather than partial nucleotide or amino acid sequence analyses, as was done previously [2,63,64]. These two USUV strains are $97 \%$ and 99\% identical at nucleotide and amino acid levels, respectively [62]. When comparing USUV to other JEV serocomplex viruses, the closest relative is MVEV that exhibits $73 \%$ and $82 \%$ identity at the nucleotide and amino acid levels, respectively. JEV and WNV exhibit $71 \%$ and $68 \%$ identity with USUV at the nucleotide level and $81 \%$ and $75 \%$ at amino acid level, respectively [62].

The phylogeny of important flaviviruses, including USUV, based on complete genome and polyprotein precursor sequence analyses is shown in Figure 3. The phylogenetic trees are constructed by the 
neighbor-joining method using MEGA [65]. The relative accession numbers of selected sequences are listed in Table 2.
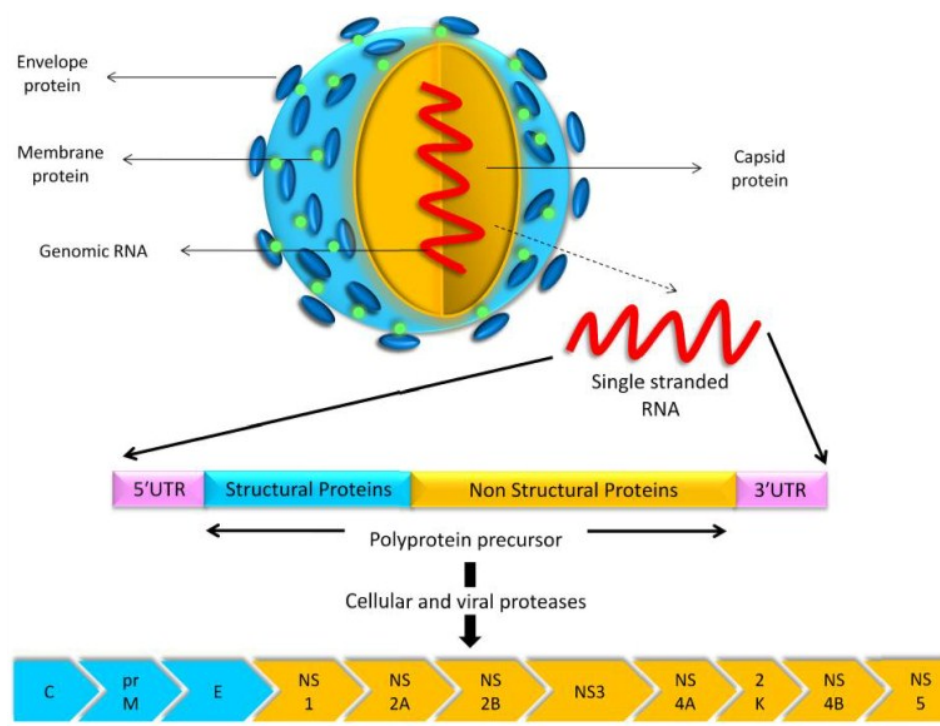

Figure 2. USUV model, its gene structure, and the proteins encoded by its genome. The polyprotein precursor is cleaved by cellular and viral proteases to yield three structural proteins (C, prM, and E) and eight non-structural proteins (NS1, NS2A, NS2B, NS3, NS4A, $2 \mathrm{~K}, \mathrm{NS} 4 \mathrm{~B}$, and NS5).

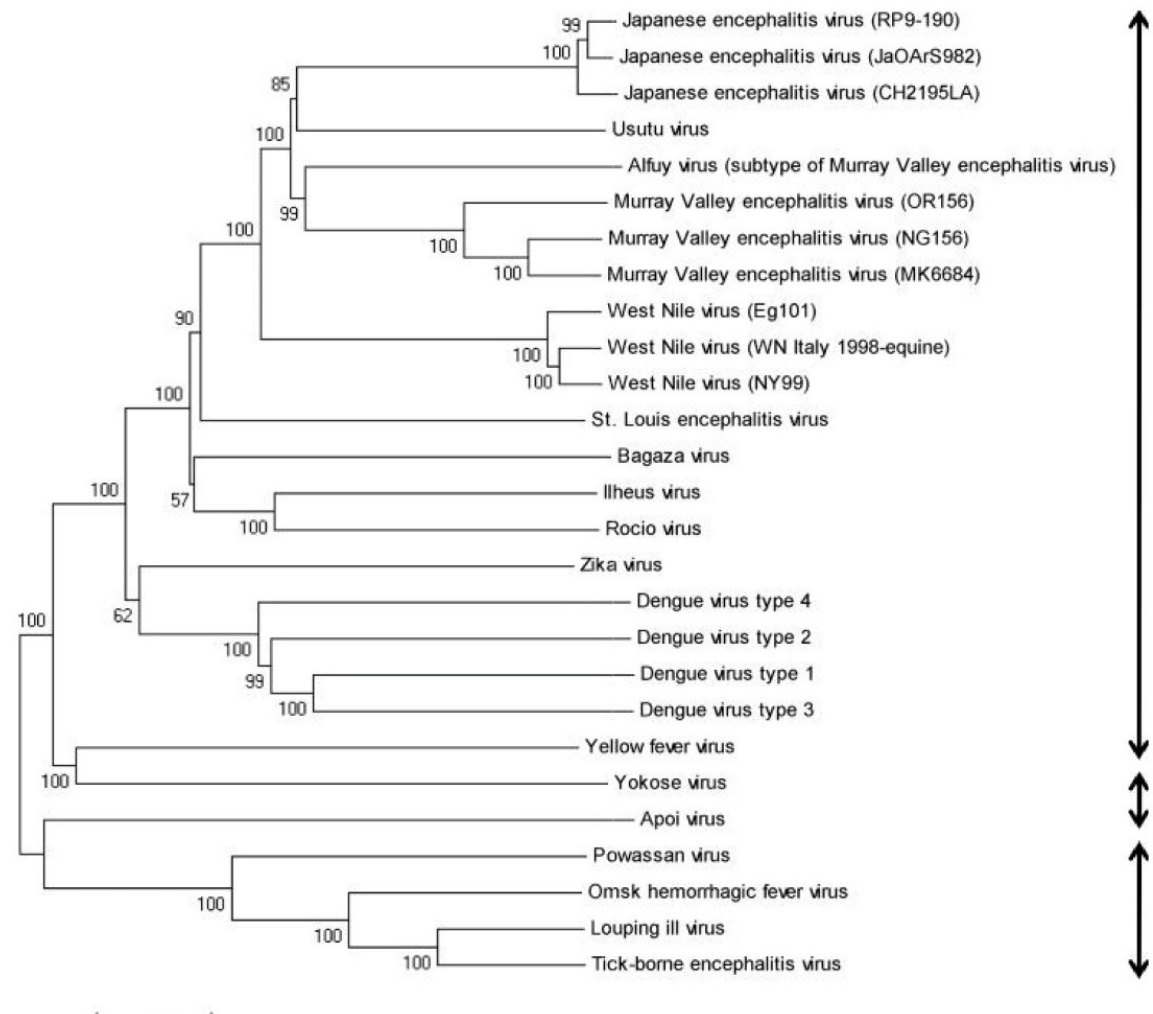

Mosquito-borne flaviviruses

No known vector

Tick-borne flaviviruses

\section{(A)}

Figure 3. Cont 


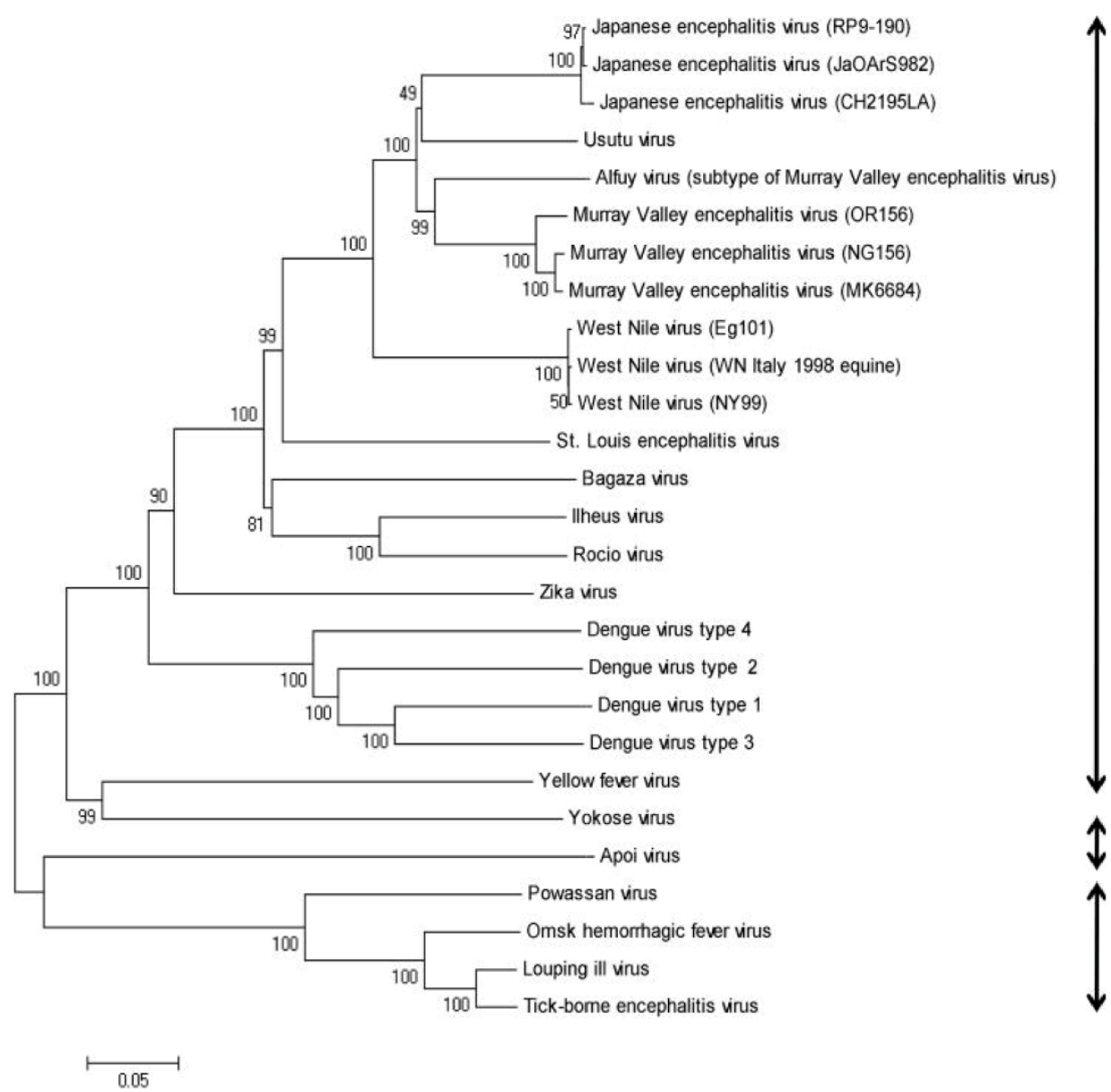

Mosquito-borne flaviviruses

No known vector

Tick-borne flaviviruses

Figure 3. (A) Phylogenetic tree based on complete genome sequence analysis. This figure illustrates the close genetic relationship between USUV and MVEV, WNV, and JEV. The relative accession numbers of selected flavivirus sequences are listed in Table 2. The number at each node is the percentage of 1000 bootstrap replicates. (B) Phylogenetic tree based on polyprotein precursor sequence analysis. This figure illustrates the close genetic relationship between USUV and MVEV, WNV, and JEV. The relative accession numbers of selected flavivirus sequences are listed in Table 2. The number at each node is the percentage of 1000 bootstrap replicates.

Table 2. Complete genome sequences and complete polyprotein precursor sequences used for the phylogenetic analyses.

\begin{tabular}{ccc}
\hline Virus Name & $\begin{array}{c}\text { Nucleotide Accession } \\
\text { Number }\end{array}$ & $\begin{array}{c}\text { Protein Accession } \\
\text { Number }\end{array}$ \\
\hline Alfuy virus & AY898809 & AAX82481 \\
Apoi virus & NC_003676 & NP_620045 \\
Bagaza virus & HQ644144 & AEI27245 \\
Dengue virus type 1 & AF309641 & AAK62993 \\
Dengue virus type 2 & M29095 & AAA42941 \\
Dengue virus type 3 & AY679147 & AAT79552 \\
\hline
\end{tabular}


Table 2. Cont.

\begin{tabular}{ccc}
\hline Virus Name & $\begin{array}{c}\text { Nucleotide Accession } \\
\text { Number }\end{array}$ & $\begin{array}{c}\text { Protein Accession } \\
\text { Number }\end{array}$ \\
\hline Dengue virus type 4 & AF326573 & AAK01233 \\
Ilheus virus & KC481679 & AGJ84083 \\
Japanese encephalitis virus (CH2195LA) & AF221499 & AAF34186 \\
Japanese encephalitis virus (JaOArS982) & M18370 & AAA81554 \\
Japanese encephalitis virus (RP9-190) & KF907505 & AHK05344 \\
Louping ill virus & KF056331 & AGN32859 \\
Murray Valley encephalitis virus (MK6684) & KF751869 & AIA58169 \\
Murray Valley encephalitis virus (NG156) & KF751870 & AIA58170 \\
Murray Valley encephalitis virus (OR156) & KF751871 & AIA58171 \\
Omsk hemorrhagic fever virus & AY193805 & AAP29989 \\
Powassan virus & L06436 & AAA02739 \\
Rocio virus & AY632542 & AAV34158 \\
St. Louis encephalitis virus & NC_007580 & YP_001008348 \\
Tick-borne encephalitis virus & KF151173 & AGP05331 \\
Usutu virus & AY453412 & AAS59401 \\
West Nile virus (Eg101) & AF260968 & AAG02039 \\
West Nile virus (NY99) & DQ211652 & ABA62343 \\
West Nile virus (WN Italy 1998-equine) & AF404757 & AAM81753 \\
Yellow fever virus & DQ235229 & ABB69689 \\
Yokose virus & NC_005039 & NP_872627 \\
Zika virus & AY632535 & AAV34151 \\
\hline
\end{tabular}

\section{Genetic Diversity among Different USUV Strains}

Many USUV strains have been identified and sequenced. Of these strains, the genomes of only 15 have been sequenced completely (Table 3), whereas the remaining strains have been only partially sequenced $[15,46,47,66]$. When compared with the reference strain (SouthAfrica-1959), all of the completely sequenced strains, except CAR-1969, exhibit $97 \%$ and $99 \%$ similarity at the nucleotide and amino acid levels, respectively, whereas CAR-1969 shares 81\% nucleotide and 95\% amino acid similarity. These data were confirmed by BLAST analysis (http://www.ncbi.nlm.nih.gov/blast).

The comparative analysis of the polyprotein precursor of all completely sequenced strains, except CAR-1969, to the reference strain revealed amino acid substitutions at specific positions (Figure 4) [15,26,46,47]. A total of 11 amino acid substitutions (G569S, T716P, N790S, R1117K, N1267D, L1695M, R2030I, E2032Q, L2166F, S2290G, and S2849G) are common in all strains. However, certain substitutions are seen in particular strains, which may contribute to yet unknown strain-specific characteristics. These distinct substitutions are present in Kedougou-1974 (I283V, R891K, V1190I, F1240L, A1436T, V1492I, and K2706R), CAR-1981 (S1299L, Y1977H, and H2702Q), Barkedji-1993 (C994W and I1179V), Vienna-2001 (A1779V and F2367L), MeiseH-2002 (I822V and X2483L), Budapest-2005 (I176T and I1197T), Spain BM119/06 (R101K, L112V, M153T, G172D, G273S, V454A, I563V, V636A, Y967H, I1067V, V1227A, F1270L, V1460I, R1645K, Y1771H, D1791H, S1981G, I2009V, V2075I, H2301P, T2355N, E2552D, D2695E, K2902R, Y3055H, and I3322V), 
Barkedji-2007 (A30V, L568S, D1942E, N1983S, N2296S, and C2662Y), Italy-2009 (R181K and L3363P), Bologna-2009 (D3425E), BAT1USUTU-BNI (Q306E, V1841A, and M1870K), and BAT2USUTU-BNI (M3350V). Interestingly, S595G and D3425E substitutions in Bologna-2009 are considered important because they might have played a role in promoting the human-specific neuroinvasive capacity of this virus [47]. These substitutions are not seen in CAR-1981, which was associated with symptoms, such as fever and rash in a man [6]. Therefore, when comparing the two strains affecting humans, the two Bologna-2009 substitutions (S595G and D3425E) may contribute to the difference in virulence between them. Moreover, the Bologna-2009-related substitutions (S595G and $\mathrm{D} 3425 \mathrm{E}$ ) are common to some other flaviviruses (DENV, JEV, WNV, and MVEV) that also threaten human health [47]. DENV-2 isolates in Southern-Asia associated with human encephalitis [67] and Bologna-2009 have the same amino acid (serine) at position 595 in the DIII-Ir domain of the E protein [47]. Domain DIII of the E protein of flaviviruses is the likely receptor binding domain and the major determinant of virus cellular tropism [68]. Specific amino acid substitutions within Domain DIII of WNV have been implicated as mediators of virus infectivity, antigenicity, and virulence [69]. In addition, the D3425E substitution in Bologna-2009 is similar to that found in certain strains of JEV, WNV, and MVEV [47]. Studies on WNV have shown that substitutions in virtually equivalent positions were associated with variation in the ability of WNV to invade the central nervous system of laboratory-infected mice [70]. Furthermore, A1236V and L1549F substitutions in Mannheim-2011, BAT1USUTU-BNI, and BAT2USUTU-BNI are also considered important because similar mutations in the related WNV modulated the host antiviral response by inhibition of interferon signaling [71].

Table 3. Nucleotide and amino acid sequence similarity in fully sequenced USUV strains.

\begin{tabular}{|c|c|c|c|c|c|c|c|}
\hline Strain & $\begin{array}{c}\text { Geographical } \\
\text { Origin }\end{array}$ & $\begin{array}{l}\text { Genome } \\
\text { Length } \\
\text { (bp) } \\
\end{array}$ & $\begin{array}{c}\text { Total } \\
\text { Amino } \\
\text { Acids } \\
\end{array}$ & $\begin{array}{c}\text { Nucleotide } \\
\text { Similarity } \\
\%\end{array}$ & $\begin{array}{c}\text { Amino } \\
\text { Acid } \\
\text { Similarity } \\
\% \\
\end{array}$ & Nucleotide & Access. No \\
\hline South Africa-1959 & South Africa & 11064 & 3434 & - & - & AY453412 & AAS59401 \\
\hline CAR-1969 & CAR & 10745 & 3434 & 81 & 95 & KC754958 & AGP50649 \\
\hline Kedougou-1974 & Senegal & 10837 & 3434 & 97 & 99 & KC754954 & AGP50645 \\
\hline CAR-1981 & CAR & 10800 & 3434 & 97 & 99 & KC754955 & AGP50646 \\
\hline Barkedji-1993 & Senegal & 10837 & 3434 & 97 & 99 & KC754956 & AGP50647 \\
\hline Vienna-2001 & Austria & 11066 & 3434 & 97 & 99 & AY453411 & AAS59402 \\
\hline MeiseH-2002 & Austria & 11047 & 3434 & 97 & 99 & JQ219843 & AFE85504 \\
\hline Budapest-2005 & Hungary & 11065 & 3434 & 97 & 99 & EF206350 & ABP88817 \\
\hline Spain BM119/06 & Spain & 11064 & 3434 & 97 & 99 & KF573410 & AHA57377 \\
\hline Barkedji-2007 & Senegal & 10825 & 3434 & 97 & 99 & KC754957 & AGP50648 \\
\hline Italy-2009 & Italy & 11065 & 3434 & 97 & 99 & JF266698 & AEK21245 \\
\hline Bologna-2009 & Italy & 11065 & 3434 & 97 & 99 & HM569263 & AEF13245 \\
\hline Mannheim-2011 & Germany & 11003 & 3434 & 97 & 99 & HE599647 & CCD57503 \\
\hline BAT1USUTU-BNI & Germany & 11065 & 3434 & 97 & 99 & KJ859682 & AIN76231 \\
\hline BAT2USUTU-BNI & Germany & 11065 & 3434 & 97 & 99 & KJ859683 & AIN76232 \\
\hline
\end{tabular}




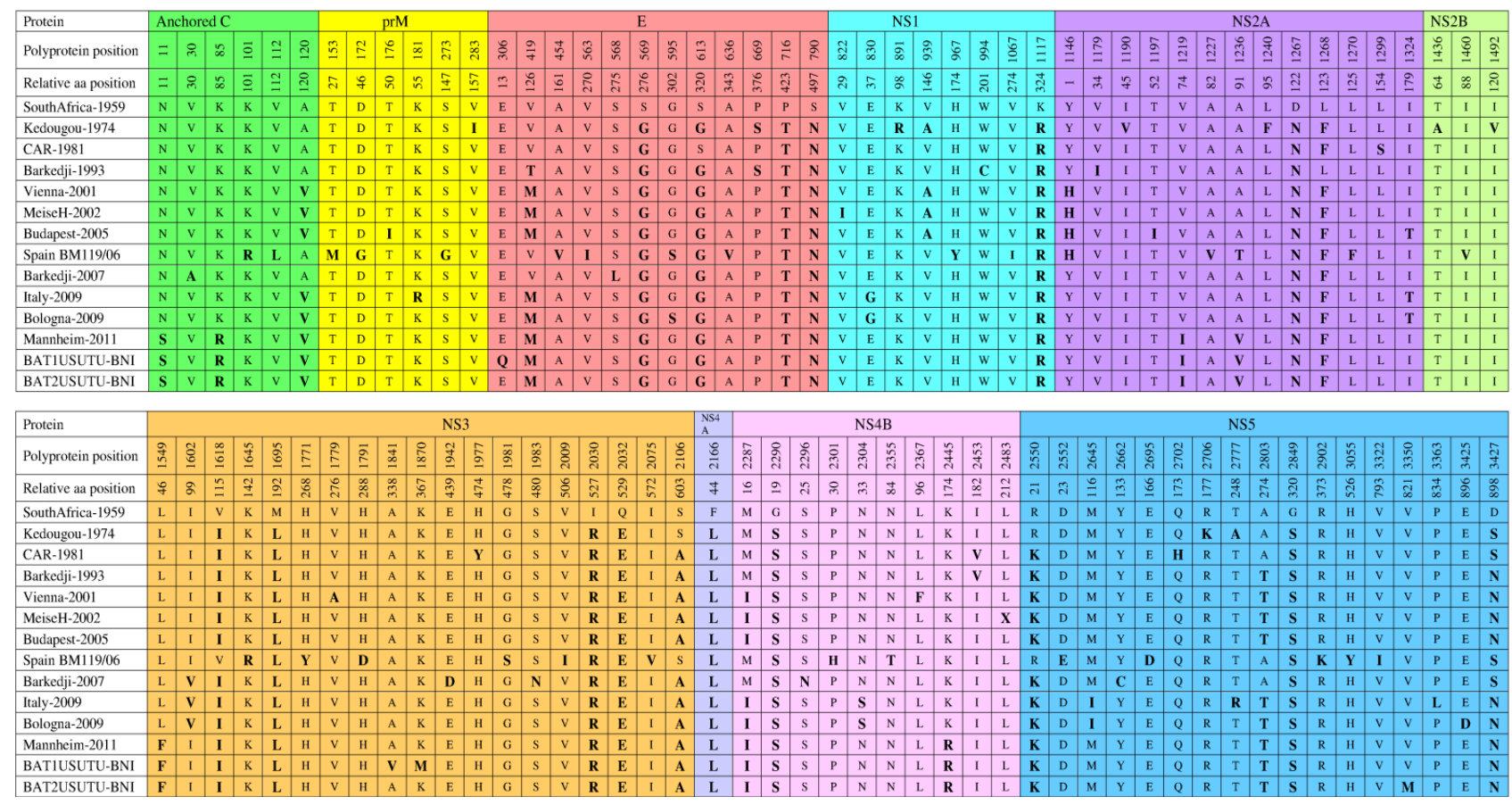

Figure 4. Comparison of polyprotein precursors of fully sequenced USUV strains. Anchored C protein (1-126), prM protein (127-293), E protein (294-793), NS1 protein (794-1145), NS2A protein (1146-1372), NS2B protein (1373-1503), NS3 protein (1504-2122), NS4A protein (2123-2248), 2K protein (2249-2271), NS4B protein (2272-2529), and NS5 protein (2530-3434). All amino acid substitutions are shown with bolded and enlarged letters.

To gain a better knowledge about these strain-specific amino acid substitutions, comparative pathogenesis studies on different USUV strains will be important using animal models.

The 5' and 3' UTRs play important roles in flavivirus genome replication and translation [72-74]. The first 96 and the last 666 nucleotides in the genomes of different USUV strains contribute to the $5^{\prime}$ and 3' UTRs, respectively [63]. Comparative analysis of all completely sequenced USUV strains, except CAR-1969, using the reference strain as a baseline revealed various nucleotide substitutions in the $5^{\prime}$ and 3' UTRs of the strains (Figure 5) [15,26,46,47]. In the 5' UTRs, all strains showed common nucleotide substitutions at positions 31, 32, and 38. At position 14, only six strains (Kedougou-1974, CAR-1981, Barkedji-1993, MeiseH-2002, Barkedji-2007, and Mannheim-2011) showed a common nucleotide substitution. At position 10, MeiseH-2002 and Mannheim-2011 showed a common nucleotide substitution. However, MeiseH-2002 showed distinct nucleotide substitutions at positions 3 and 4.

In the 3' UTRs, the nucleotide substitution scenario may be more revealing than in the 5' UTRs. The most common nucleotide substitutions were observed at positions 10428, 10558, and 10698. At positions 10898 and 10945, only European strains showed common substitutions. The pattern of distinct substitutions also varied among different USUV strains. These distinct substitutions were observed in Kedougou-1974 (positions 10409, 10429, 10435, 10455, and 10770), Barkedji-1993 (10468, 10475, and 10484), MeiseH-2002 (10557), Spain BM119/06 (10420, 10424, 10478, 10537, 10665, and 10696), Barkedji-2007 (10479 and 10659), and Bologna-2009 (11050). CAR-1981 exhibited the most distinct features in its 3' UTR with four unique substitutions (positions 10434, 10459, 10489, and 10715) and 16 nucleotide deletions (Figure 5). These deletions were not observed in the Bologna-2009 strain, 
which might have played a basic role in the capability of this isolate to infect and provoke disease in a human [46].

CAR-1969 is the most divergent strain of USUV, as mentioned earlier. Because it has the most diversity when comparing the USUV strains, historically it has been difficult to determine whether it should be classified as a separate viral species. The genetic distance between all USUV strains, including CAR-1969 (0.00-0.19 substitutions per site), which do not exceed those observed for other closely related viruses of the JEV serocomplex, namely WNV (0.00-0.22 substitutions per site) or JEV (0.01-0.21 substitutions per site), categorized it as an USUV strain [46]. Furthermore, cross-reactivity between SouthAfrica-1959 and CAR-1969 has also been demonstrated using complement fixation assay [75].

\begin{tabular}{|c|c|c|c|c|c|c|c|c|c|c|c|c|c|c|c|c|c|c|c|c|c|c|c|c|c|c|c|c|c|c|c|c|c|c|c|}
\hline Region & & & & 5 UTH & & & & & ORF & & & & & & & & & 3 UT & & & & & & & & & & & & & & & & & \\
\hline Nucleotide position & $m$ & + & $\infty$ & 은 & \pm & $\bar{m}$ & ले & $\infty$ & $97-10401$ & 敉 & 亲 & 守 & 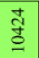 & $\begin{array}{l}\text { Tे } \\
\text { d̦ }\end{array}$ & 旁 & 蛋 & 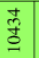 & $\begin{array}{l}\stackrel{m}{o} \\
\stackrel{q}{g}\end{array}$ & 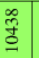 & 管 & 容 & $\begin{array}{l}\text { ầ } \\
\text { to }\end{array}$ & 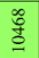 & 管 & \begin{tabular}{l}
$\infty$ \\
\multirow{2}{*}{} \\
$\underline{0}$
\end{tabular} & $\begin{array}{l}\text { tે } \\
\text { to }\end{array}$ & 啇 & 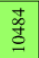 & $\begin{array}{l}\text { \& } \\
\text { d̦ }\end{array}$ & 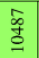 & $\begin{array}{l}\text { 总 } \\
\text { d̦ }\end{array}$ & $\begin{array}{l}\underline{d} \\
\text { do }\end{array}$ & 毫 & $\begin{array}{l}\text { 蒿 } \\
\text { d }\end{array}$ & 学 \\
\hline South Africa-1959 & $\mathrm{T}$ & C & C & $\mathrm{T}$ & C & C & A & G & ORF & $\mathrm{T}$ & G & $\mathrm{T}$ & $\mathrm{T}$ & $\mathrm{T}$ & $\mathrm{T}$ & $\mathrm{C}$ & $\mathrm{T}$ & A & $\mathrm{T}$ & A & G & A & $\mathrm{T}$ & $\mathrm{T}$ & $\mathrm{T}$ & $\mathrm{T}$ & $\mathrm{T}$ & A & C & A & $\mathrm{T}$ & A & G & G & A \\
\hline Kedougou-1974 & - & - & - & - & $\mathbf{T}$ & $\mathbf{A}$ & G & $T$ & ORF & C & G & $\mathrm{T}$ & $T$ & $\mathbf{A}$ & $\mathrm{C}$ & C & $T$ & G & $T$ & G & $\mathbf{A}$ & A & $\mathrm{T}$ & $T$ & $T$ & $T$ & $T$ & A & $\mathrm{C}$ & A & $\mathrm{T}$ & A & G & G & A \\
\hline CAR-1981 & - & - & - & - & $T$ & $\mathbf{A}$ & G & $T$ & ORF & $\mathrm{T}$ & G & $\mathrm{T}$ & $\mathrm{T}$ & $\mathbf{A}$ & $T$ & $T$ & C & A & $\mathrm{T}$ & A & A & G & $\mathrm{T}$ & $\mathrm{T}$ & $\mathrm{T}$ & $\mathrm{T}$ & $\mathrm{T}$ & A & * & * & $\mathbf{A}$ & * & * & * & * \\
\hline Barkedji-1993 & - & - & - & - & $\mathbf{T}$ & $\mathbf{A}$ & G & $T$ & ORF & $\mathrm{T}$ & G & $\mathrm{T}$ & $\mathrm{T}$ & $\mathbf{A}$ & $\mathrm{T}$ & $T$ & $\mathrm{~T}$ & A & C & A & $\mathbf{A}$ & A & $\mathrm{C}$ & C & $T$ & $\mathrm{~T}$ & $\mathrm{~T}$ & G & $\mathbf{T}$ & G & $\mathrm{T}$ & A & G & G & A \\
\hline Vienna-2001 & $\mathrm{T}$ & C & C & $\mathrm{T}$ & $\mathrm{C}$ & $\mathbf{A}$ & G & $T$ & ORF & $\mathrm{T}$ & G & C & $\mathrm{T}$ & $\mathbf{A}$ & $\mathrm{T}$ & $T$ & $\mathrm{~T}$ & A & C & A & $\mathbf{A}$ & A & $\mathrm{T}$ & $\mathrm{T}$ & $\mathrm{T}$ & $\mathrm{T}$ & $\mathrm{C}$ & A & $T$ & G & $\mathrm{T}$ & A & G & G & A \\
\hline MeiseH-2002 & A & $T$ & C & C & $\mathbf{T}$ & $\mathbf{A}$ & G & $\mathbf{T}$ & ORF & $\mathrm{T}$ & G & C & $\mathrm{T}$ & $\mathbf{A}$ & $T$ & $T$ & $\mathrm{~T}$ & A & C & A & $\mathbf{A}$ & A & $\mathrm{T}$ & $T$ & $\mathrm{~T}$ & $\mathrm{~T}$ & C & A & $T$ & G & $\mathrm{T}$ & A & G & G & A \\
\hline Budapest-2005 & $\mathrm{T}$ & $\mathrm{C}$ & $\mathrm{C}$ & $\mathrm{T}$ & $\mathrm{C}$ & $\mathbf{A}$ & G & $T$ & ORF & $\mathrm{T}$ & G & C & $\mathrm{T}$ & $\mathbf{A}$ & $\mathrm{T}$ & $T$ & $\mathrm{~T}$ & A & C & A & $\mathbf{A}$ & A & $\mathrm{T}$ & $\mathrm{T}$ & $\mathrm{T}$ & $\mathrm{T}$ & $\mathrm{C}$ & A & $\mathbf{T}$ & G & $\mathrm{T}$ & A & G & G & A \\
\hline Spain BM119/06 & $\mathrm{T}$ & $\mathrm{C}$ & C & $\mathrm{T}$ & $\mathrm{C}$ & $\mathbf{A}$ & G & $T$ & ORF & $\mathrm{T}$ & $\mathbf{A}$ & C & $\mathrm{C}$ & $\mathbf{A}$ & $\mathrm{T}$ & $\mathrm{C}$ & $\mathrm{T}$ & A & $\mathrm{T}$ & A & G & A & $\mathrm{T}$ & $\mathrm{T}$ & C & $\mathrm{T}$ & $\mathrm{C}$ & A & $\mathrm{C}$ & A & $\mathrm{T}$ & A & G & G & A \\
\hline Barkedji-2007 & - & - & - & - & $\mathbf{T}$ & $\mathbf{A}$ & G & $\mathbf{T}$ & ORF & $\mathrm{T}$ & G & $\mathrm{T}$ & $\mathrm{T}$ & A & $\mathrm{T}$ & $\mathrm{C}$ & $\mathrm{T}$ & A & $\mathbf{A}$ & A & A & A & $\mathrm{T}$ & $\mathrm{T}$ & $\mathrm{T}$ & C & C & A & $\mathbf{T}$ & A & $\mathrm{T}$ & A & G & G & A \\
\hline Italy-2009 & $\mathrm{T}$ & $\mathrm{C}$ & C & $\mathrm{T}$ & C & A & G & $\mathbf{T}$ & ORF & $\mathrm{T}$ & G & $\mathrm{T}$ & $\mathrm{T}$ & A & $\mathrm{T}$ & $T$ & $\mathrm{~T}$ & A & C & A & A & A & $\mathrm{T}$ & $\mathrm{T}$ & $\mathrm{T}$ & $\mathrm{T}$ & C & A & $\mathbf{T}$ & G & $\mathrm{T}$ & A & G & G & A \\
\hline Bologna-2009 & $\mathrm{T}$ & c & $\mathbf{T}$ & $\mathrm{T}$ & c & $\mathbf{A}$ & G & $\mathbf{T}$ & ORF & $\mathrm{T}$ & G & $\mathrm{T}$ & $\mathrm{T}$ & A & $\mathrm{T}$ & $T$ & $\mathrm{~T}$ & A & C & A & A & A & $\mathrm{T}$ & $\mathrm{T}$ & $\mathrm{T}$ & $\mathrm{T}$ & C & A & $\mathbf{T}$ & G & $\mathrm{T}$ & A & G & G & A \\
\hline Mannheim-2011 & - & - & - & C & $T$ & A & G & $T$ & ORF & $\mathrm{T}$ & G & C & $\mathrm{T}$ & A & $\mathrm{T}$ & $T$ & $\mathrm{~T}$ & A & C & A & A & A & $\mathrm{T}$ & $\mathrm{T}$ & $\mathrm{T}$ & $\mathrm{T}$ & C & A & $\mathbf{T}$ & G & $\mathrm{T}$ & A & G & G & A \\
\hline BAT1USUTU-BN1 & $\mathrm{T}$ & C & C & $\mathrm{T}$ & C & $\mathbf{A}$ & G & $\mathbf{T}$ & ORF & $\mathrm{T}$ & G & C & $\mathrm{T}$ & A & $\mathrm{T}$ & $\mathbf{T}$ & $\mathrm{T}$ & A & C & A & A & A & $\mathrm{T}$ & $\mathrm{T}$ & $\mathrm{T}$ & $\mathrm{T}$ & C & A & $\mathbf{T}$ & G & $\mathrm{T}$ & A & G & G & A \\
\hline BAT2USUTU-BN1 & $\mathrm{T}$ & C & C & $\mathrm{T}$ & C & $\mathbf{A}$ & G & $T$ & ORF & $\mathrm{T}$ & G & C & $\mathrm{T}$ & $\mathbf{A}$ & $T$ & $\mathbf{T}$ & $T$ & A & C & A & $\mathbf{A}$ & A & $T$ & $T$ & $\mathrm{~T}$ & $\mathrm{~T}$ & C & A & $T$ & G & $\mathrm{T}$ & A & G & G & A \\
\hline
\end{tabular}

\begin{tabular}{|c|c|c|c|c|c|c|c|c|c|c|c|c|c|c|c|c|c|c|c|c|c|c|c|c|c|c|c|c|c|c|c|c|c|c|c|}
\hline \multicolumn{36}{|l|}{ Region } \\
\hline Nucleotide position & 衰 & 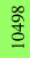 & 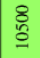 & 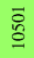 & 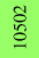 & t. & $\begin{array}{l}\qquad \\
\vdots \\
\varrho\end{array}$ & $\begin{array}{l}\mathscr{8} \\
\stackrel{0}{0}\end{array}$ & 总 & 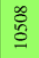 & $\stackrel{ }{\stackrel{0}{g}}$ & $\stackrel{m}{\vec{s}}$ & $\frac{n}{8}$ & हิ & 气ิ & $\begin{array}{l}\infty \\
\mho \\
\delta\end{array}$ & శ్రి & है & $\begin{array}{l}\mathbb{f} \\
\stackrel{f}{8}\end{array}$ & है & $\begin{array}{l}\tilde{\delta} \\
\stackrel{0}{0}\end{array}$ & $\begin{array}{l}\ddot{0} \\
\stackrel{0}{0}\end{array}$ & \&̊ㅇ & $\stackrel{\circ}{\stackrel{0}{\circ}}$ & $\frac{n}{5}$ & 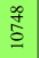 & ڤ్ & $\begin{array}{l}\overline{\tilde{d}} \\
\stackrel{0}{\circ}\end{array}$ & $\begin{array}{l}\stackrel{\circ}{\circ} \stackrel{\circ}{\stackrel{0}{0}}\end{array}$ & $\stackrel{\infty}{\varnothing ్ ర ీ}$ & 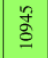 & \& & $\stackrel{\infty}{\varrho}$ & 总 & $\stackrel{\circ}{\circ}$ \\
\hline South Africa-1959 & A & A & A & G & A & $\mathrm{G}$ & $\mathrm{T}$ & $\mathrm{T}$ & G & A & $\mathrm{T}$ & $\mathrm{G}$ & A & A & G & $\mathrm{T}$ & A & G & A & A & $\mathrm{T}$ & $\mathrm{T}$ & C & G & A & $\mathrm{T}$ & C & * & $\mathrm{G}$ & A & */A & */A & $\mathrm{C}$ & G & $\mathrm{T}$ \\
\hline Kedougou-1974 & A & G & A & G & A & G & $\mathrm{T}$ & $\mathrm{T}$ & $\mathbf{A}$ & A & G & $T$ & A & A & G & C & $T$ & G & A & A & $\mathrm{T}$ & $\mathrm{T}$ & C & $\mathbf{A}$ & A & $\mathrm{T}$ & $\mathrm{T}$ & G & - & - & - & - & - & - & - \\
\hline CAR-1981 & ${ }^{*}$ & * & $*$ & * & * & * & * & $*$ & G & $*$ & $\mathrm{~T}$ & * & A & A & G & C & A & $\mathbf{A}$ & A & A & $\mathrm{T}$ & $\mathrm{T}$ & C & $\mathbf{A}$ & G & $\mathrm{T}$ & C & $\mathrm{G}$ & - & - & - & - & - & - & - \\
\hline Barkedji-1993 & A & G & A & G & A & G & $\mathrm{T}$ & $\mathrm{T}$ & A & A & G & $\mathbf{T}$ & A & A & G & C & A & $\mathbf{A}$ & A & A & $\mathrm{T}$ & C & c & $\mathbf{A}$ & A & $\mathrm{T}$ & C & G & - & - & - & - & - & - & - \\
\hline Vienna-2001 & $\mathrm{A}$ & G & A & G & A & G & $\mathrm{T}$ & $\mathrm{T}$ & $\mathbf{A}$ & A & G & $T$ & $\mathrm{~A}$ & A & G & $\mathrm{C}$ & $\mathrm{A}$ & $\mathbf{A}$ & G & A & $\mathrm{T}$ & $\mathrm{C}$ & c & $\mathbf{A}$ & A & $\mathbf{C}$ & $\mathrm{C}$ & G & $\mathbf{A}$ & A & A & $\mathrm{A}$ & $\mathrm{C}$ & G & $\mathrm{T}$ \\
\hline MeiseH-2002 & A & G & A & G & A & G & $\mathrm{T}$ & $\mathrm{T}$ & A & A & G & $T$ & A & A & $\mathbf{A}$ & $\mathrm{C}$ & A & $\mathbf{A}$ & G & A & $\mathrm{T}$ & C & $\mathrm{c}$ & $\mathbf{A}$ & A & $\mathrm{C}$ & $\mathrm{C}$ & G & $\mathbf{A}$ & A & $\mathbf{A}$ & A & $T$ & G & - \\
\hline Budapest-2005 & A & G & A & G & A & G & $\mathrm{T}$ & $\mathrm{T}$ & $\mathbf{A}$ & A & G & $\mathbf{T}$ & A & A & G & $\mathrm{C}$ & A & $\mathbf{A}$ & G & A & $\mathrm{T}$ & $\mathrm{C}$ & $\mathrm{C}$ & $\mathbf{A}$ & A & $\mathrm{C}$ & $\mathrm{C}$ & G & $\mathbf{A}$ & A & $\mathbf{A}$ & A & $\mathrm{C}$ & G & $\mathrm{T}$ \\
\hline Spain BM119/06 & A & A & A & G & A & G & $\mathrm{T}$ & $\mathrm{T}$ & A & A & $\mathrm{T}$ & G & A & G & G & $\mathrm{C}$ & A & G & A & A & $\mathrm{C}$ & $\mathrm{C}$ & $T$ & $\mathbf{A}$ & A & $\mathrm{T}$ & C & $T$ & $\mathbf{A}$ & A & * & A & $\mathrm{c}$ & G & $\mathrm{T}$ \\
\hline Barkedji-2007 & A & G & A & G & A & G & $T$ & $\mathrm{~T}$ & $\mathbf{A}$ & A & G & $T$ & G & A & G & $\mathrm{C}$ & A & $\mathbf{A}$ & A & G & $\mathrm{T}$ & $T$ & $\mathrm{C}$ & $\mathbf{A}$ & A & $T$ & $\mathrm{C}$ & G & $\cdot$ & - & $\cdot$ & $\cdot$ & $\cdot$ & $\cdot$ & - \\
\hline Italy-2009 & A & G & A & G & A & G & $T$ & $\mathrm{~T}$ & $\mathbf{A}$ & A & G & $\mathbf{T}$ & A & A & G & C & A & $\mathbf{A}$ & G & A & $\mathrm{T}$ & C & $\mathrm{C}$ & $\mathbf{A}$ & A & $\mathrm{C}$ & C & G & $\mathbf{A}$ & A & $\mathbf{A}$ & A & $T$ & G & $\mathrm{T}$ \\
\hline Bologna-2009 & A & G & A & G & A & G & $\mathrm{T}$ & $\mathrm{T}$ & $\mathbf{A}$ & A & G & $T$ & G & A & G & $\mathrm{C}$ & A & $\mathbf{A}$ & G & A & $\mathrm{T}$ & C & $\mathrm{c}$ & $\mathbf{A}$ & A & $\mathrm{C}$ & C & G & $\mathbf{A}$ & A & $\mathbf{A}$ & A & $\mathrm{c}$ & A & $\mathbf{A}$ \\
\hline Mannheim-2011 & A & G & A & G & A & G & $T$ & $\mathrm{~T}$ & $\mathbf{A}$ & A & G & $\mathbf{T}$ & A & A & G & C & G & $\mathbf{A}$ & G & A & $\mathrm{T}$ & C & $\mathrm{C}$ & $\mathbf{A}$ & A & $\mathrm{C}$ & $\mathrm{C}$ & G & $\mathbf{A}$ & G & $\mathbf{A}$ & A & - & - & - \\
\hline BAT1USUTU-BN1 & A & G & A & G & A & G & $T$ & $\mathrm{~T}$ & $\mathbf{A}$ & A & G & $T$ & A & A & G & $\mathrm{C}$ & G & $\mathbf{A}$ & G & A & $T$ & C & $\mathrm{C}$ & $\mathbf{A}$ & A & $\mathrm{C}$ & C & G & $\mathbf{A}$ & G & $\mathbf{A}$ & A & C & $\mathbf{A}$ & $\mathrm{T}$ \\
\hline BAT2USUTU-BN1 & A & G & A & G & A & G & $\mathrm{T}$ & $\mathrm{T}$ & A & A & G & $\mathrm{T}$ & A & A & G & C & G & A & G & A & $\mathrm{T}$ & C & $\mathrm{C}$ & A & A & C & C & G & A & G & A & A & $\mathrm{c}$ & G & $\mathrm{T}$ \\
\hline
\end{tabular}

Figure 5. Comparison of 5' UTRs and 3' UTRs of fully sequenced USUV strains. 5' UTR (1-96), open reading frame (ORF;97-10,401), 3' UTR (10,402-11,064). All nucleotide substitutions are shown with bolded and enlarged letters. Nucleotide deletions are indicated by an asterisk (*).

\section{Diagnosis}

The occurrence of human cases of USUV infection has underscored the need to develop reliable and confirmatory diagnostic tools for detection. In this regard, Cavrini et al. developed the first rapid, USUV-specific real-time RT-PCR assay based on Austrian and Hungarian strain sequences [76]. This assay could detect USUV in human blood and cerebrospinal fluid samples with high specificity and sensitivity, but its detection reliability was limited to a few European strains. This limitation was overcome by another recently developed real-time RT-PCR assay based on African and European strain sequences [77]. These diagnostic assays allow the detection of USUV in blood and cerebrospinal fluid 
samples at the viremic stage; therefore, serological testing is important to identify the infection following the viremic stage.

In 2012, Gaibani et al. developed the first USUV-specific IgG-capture ELISA assay for serological diagnosis of USUV [49]. This assay can detect USUV-specific IgGs in both Italian and German healthy blood donors, as mentioned earlier [48,49]; cross-reactivity between USUV and WNV was resolved by adapting a diagnostic algorithm [78] and the plaque reduction neutralization test [49]. The latter test is a current standard to discriminate between closely related flaviviruses [49]. Interestingly, in flaviviruses, cross-reactivity is higher for IgG than for IgM [79]; therefore, USUV-specific IgM-based assays must be developed. Considering that USUV infections have been documented throughout Europe and that few approaches are available for reliable detection and diagnosis, the scope of USUV-related diagnosis is wide open, and additional efforts are needed to adequately prepare for a possible large-scale USUV outbreak.

\section{Conclusions}

In Africa, USUV is typically isolated from mosquitoes and generally infects only four avian species, namely Bycanistes sharpei (piping hornbill), Andropadus virens (little greenbul), Turdus libonyanus (Kurrichane thrush), and T. merula (blackbird) [35]. However, the non-migratory behavior of these species suggests that they have not been involved in dispersing USUV throughout Europe. In Austria (2005), a serological study demonstrated the presence of USUV-specific antibodies in several migratory bird species, including Sylvia communis (whitethroat), Sylvia curruca (lesser whitethroat), Sylvia borin (garden warbler), Falco tinnunculus (kestrel), Circus aeruginosus (marsh harrier), Delichon urbica (house martin), Acrocephalus scirpaceus (reed warbler), Ficedula hypoleuca (pied flycatcher), and Hirundo rustica (barn-swallow) [80]. Based on their migratory habits and the presence of USUV-specific antibodies, these bird species may have played a role in the introduction of USUV into Europe, but further investigation into this possibility is still needed. Moreover, Cx. pipiens mosquitoes and Eurasian blackbirds (T. merula) are two important causes of USUV dissemination in Europe [16-21,25-28].

The migration pattern of blackbirds brings them in Eastern Asian countries, including Eastern Russia, Eastern China, Taiwan, Korea, and Japan [81], whereas Cx. pipiens mosquitoes are also common in Asian countries [82-84]. Considering these factors, USUV might be a potential threat to populations in Asia. However, competence studies of the local population of the potential vectors should be evaluated for real risk assessment in Asian countries. To prevent the emergence of USUV on a larger scale, veterinary-, human-, and entomology-based surveillance programs should be established throughout Europe.

Newly developed USUV-specific real-time RT-PCR assays and ELISA are very helpful for screening and diagnostics [49,77]. However, attaining a USUV-specific serological diagnosis will be quite challenging in certain areas where other flaviviruses occur along with USUV. Such potential cross-reactivities must be ruled out by plaque reduction neutralization test. An inactivated Japanese encephalitis vaccine formulated with Advax adjuvant has induced a cross-protective immune response against MVEV and WNV [85,86]. Because USUV is a member of the JEV serocomplex, Japanese encephalitis-Advax vaccine might be an alternate approach to control USUV infection, and, thus, threat to Asia can be reduced in JEV-immune populations. Furthermore, a recently developed WNV recombinant subviral 
particle vaccine showed a cross-reactive humoral response against USUV in mice [87]. A multidimensional approach is also necessary for effective USUV-related risk assessment and to determine the involvement of various elements (bird, mosquito, human, rodents, and horses) in the USUV infection cycle.

\section{Acknowledgments}

This work was supported by Chinese national special research programs for non-profit trades (200903037), 863 programs (2011AA10A2), and 948 programs (2011-G24).

\section{Author Contributions}

U.A., J.Y., and S.C. wrote the manuscript. U.A. and X.R. prepared the figures. U.A, S.W., and B.Z. contributed to the section on the genomic structure and phylogenetic analysis of USUV.

\section{Conflicts of Interest}

The authors declare no conflict of interest.

\section{References}

1. Karabatsos, N. Usutu virus. In International Catalogue of Arboviruses Including Certain other Viruses of Vertebrates, 3rd ed.; The American Society of Tropical Medicine and Hygiene: San Antonio, TX, USA, 1985; pp. 1059-1060.

2. Kuno, G.; Chang, G.J.; Tsuchiya, K.R.; Karabatsos, N.; Cropp, C.B. Phylogeny of the genus Flavivirus. J. Virol. 1998, 72, 73-83.

3. Poidinger, M.; Hall, R.A.; Mackenzie, J.S. Molecular characterization of the Japanese encephalitis serocomplex of the Flavivirus genus. Virology 1996, 218, 417-421.

4. Calisher, C.H.; Gould, E.A. Taxonomy of the virus family Flaviviridae. Adv. Virus Res. 2003, 59, 1-19.

5. Woodall, J.P. The viruses isolated from arthropods at the East African virus research institute in the 26 years ending December 1963. Proc. E. Afr. Acad. 1964, 2, 141-146.

6. Adam, F.; Digoutte, J.-P. Virus d' Afrique (base de donnes). In Centre Collaborateur OMS de Référence et de Recherche Pour les Arbovirus et les Virus de Fièvreshémorrhagiques (CRORA); Institut Pasteur de Dakar: Dakar, Senegal. Available online: http://www.pasteur.fr/recherche/ banques/CRORA/ (accessed on 12 July 2014).

7. Weissenböck, H.; Kolodziejek, J.; Url, A.; Lussy, H.; Rebel-Bauder, B.; Nowotny, N. Emergence of Usutu virus, an African mosquito-borne flavivirus of the Japanese encephalitis virus group, central Europe. Emerg. Infect. Dis. 2002, 8, 652-656.

8. Mani, P.; Rossi, G.; Perrucci, S.; Bertini, S. Mortality of Turdus merula in Tuscany. Sel. Vet. 1998, 8, 749-753. (In Italian)

9. Weissenböck, H.; Bakonyi, T.; Rossi, G.; Mani, P.; Nowotny, N. Usutu virus, Italy, 1996. Emerg. Infect. Dis. 2013, 19, 274-277. 
10. Vázquez, A.; Ruiz, S.; Herrero, L.; Moreno, J.; Molero, F.; Magallanes, A.; Sánchez-Seco, M.P.; Figuerola, J.; Tenorio, A. West Nile and Usutu viruses in mosquitoes in Spain, 2008-2009. Am. J. Trop. Med. Hyg. 2011, 85, 178-181.

11. Steinmetz, H.W.; Bakonyi, T.; Weissenböck, H.; Hatt, J.M.; Eulenberger, U.; Robert, N.; Hoop, R.; Nowotny, N. Emergence and establishment of Usutu virus infection in wild and captive avian species in and around Zurich, Switzerland-genomic and pathologic comparison to other central European outbreaks. Vet. Microbiol. 2011, 148, 207-212.

12. Pecorari, M.; Longo, G.; Gennari, W.; Grottola, A.; Sabbatini, A.; Tagliazucchi, S.; Savini, G.; Monaco, F.; Simone, M.; Lelli, R.; et al. First human case of Usutu virus neuroinvasive infection, Italy, August-September 2009. Euro. Surveill. 2009, 14, e19446.

13. Cavrini, F.; Gaibani, P.; Longo, G.; Pierro, A.M.; Rossini, G.; Bonilauri, P.; Gerunda, G.E.; di Benedetto, F.; Pasetto, A.; Girardis, M.; et al. Usutu virus infection in a patient who underwent orthotropic liver transplantation, Italy, August-September 2009. Euro. Surveill. 2009, 14, e19448.

14. Savini, G.; Monaco, F.; Terregino, C.; di Gennaro, A.; Bano, L.; Pinoni, C.; de Nardi, R.; Bonilauri, P.; Pecorari, M.; di Gialleonardo, L.; et al. Usutu virus in Italy: An emergence or a silent infection? Vet. Microbiol. 2011, 151, 264-274.

15. Cadar, D.; Becker, N.; Campos Rde, M.; Börstler, J.; Jöst, H.; Schmidt-Chanasit, J. Usutu virus in bats, Germany, 2013. Emerg. Infect. Dis. 2014, 20, 1771-1773.

16. Calzolari, M.; Bonilauri, P.; Bellini, R.; Albieri, A.; Defilippo, F.; Maioli, G.; Galletti, G.; Gelati, A.; Barbieri, I.; Tamba, M.; et al. Evidence of simultaneous circulation of West Nile and Usutu viruses in mosquitoes sampled in Emilia-Romagna region (Italy) in 2009. PLoS One 2010, 5, e14324.

17. Busquets, N.; Alba, A.; Allepuz, A.; Aranda, C.; Ignacio Nuñez, J. Usutu virus sequences in Culex pipiens (Diptera: Culicidae), Spain. Emerg. Infect. Dis. 2008, 14, 861-863.

18. Calzolari, M.; Gaibani, P.; Bellini, R.; Defilippo, F.; Pierro, A.; Albieri, A.; Mailoli, G.; Luppi, A.; Rossini, G.; Balzani, A.; et al. Mosquito, bird, and human surveillance of West Nile and Usutu viruses in Emilia-Romagna region (Italy) in 2010. PLoS One 2012, 7, e38058.

19. Calzolari, M.; Bonilauri, P.; Bellini, R.; Albieri, A.; Defilippo, F.; Tamba, M.; Tassinari, M.; Gelati, A.; Cordioli, P.; Angelini, P.; et al. Usutu virus persistence and West Nile virus inactivity in the Emilia-Romagna region (Italy) in 2011. PLoS One 2013, 8, e63978.

20. Tamba, M.; Bonilauri, P.; Bellini, R.; Calzolari, M.; Albieri, A.; Sambri, V.; Dottori, M.; Angelini, P. Detection of Usutu virus within a West Nile virus surveillance program in northern Italy. Vector Borne Zoonotic Dis. 2011, 11, 551-557.

21. Jöst, H.; Bialonski, A.; Maus, D.; Sambri, V.; Eiden, M.; Groschup, M.H.; Günther, S.; Becker, N.; Schmidt-Chanasit, J. Isolation of Usutu virus in Germany. Am. J. Trop. Med. Hyg. 2011, 85, 551-553.

22. Cornet, M.; Robin, Y.; Chateau, R.; Heme, G.; Adam, C.; Valade, M.; Le Gonidec, G.; Jan, C.; Renaudet, J.; Dieng, P.Y.; et al. Isolementd'arbovirus au Sénégal Oriental a partir de moustiques (1972-1977) et notes surl'épidémiologie des virus transmis par les Aedes en particulier du virus amaril. Cahiers ORSTOM. Sér. Entomologieméd. Parasitol. 1979, 17, 149-163.

23. Hubálek, Z. Pathogenic microorganisms associated with free-living birds (a review). Acta Sci. Nat. Brno. 1994, 28, 1-74. 
24. Nikolay, B.; Diallo, M.; Faye, O.; Boye, C.S.; Sall, A.A. Vector competence of Culex neavei (Diptera: Culicidae) for Usutu virus. Am. J. Trop. Med. Hyg. 2012, 86, 993-996.

25. Bakonyi, T.; Erdélyi, K.; Ursu, K.; Ferenczi, E.; Csörgo, T.; Lussy, H.; Chvala, S.; Bukovsky, C.; Meister, T.; Weissenböck, H.; et al. Emergence of Usutu virus in Hungary. J. Clin. Microbiol. 2007, 45, 3870-3874.

26. Becker, N.; Jöst, H.; Ziegler, U.; Eiden, M.; Höper, D.; Emmerich, P.; Fichet-Calvet, E.; Ehichioya, D.U.; Czajka, C.; Gabriel, M.; et al. Epizootic emergence of Usutu virus in wild and captive birds in Germany. PLoS One 2012, 7, e32604.

27. Weissenböck, H.; Kolodziejek, J.; Fragner, K.; Kuhn, R.; Pfeffer, M.; Nowotny, N. Usutu virus activity in Austria, 2001-2002. Microbes Infect. 2003, 5, 1132-1136.

28. Chvala, S.; Bakonyi, T.; Bukovsky, C.; Meister, T.; Brugger, K.; Rubel, F.; Nowotny, N.; Weissenböck, H. Monitoring of Usutu virus activity and spread by using dead bird surveillance in Austria, 2003-2005. Vet. Microbiol. 2007, 122, 237-245.

29. Garigliany, M.M.; Marlier, D.; Tenner-Racz, K.; Eiden, M.; Cassart, D.; Gandar, F.; Beer, M.; Schmidt-Chanasit, J.; Desmecht, D. Detection of Usutu virus in a bullfinch (Pyrrhula pyrrhula) and a great spotted woodpecker (Dendrocopos major) in north-west Europe. Vet. J. 2014, 199, 191193.

30. Chaintoutis, S.C.; Dovas, C.I.; Papanastassopoulou, M.; Gewehr, S.; Danis, K.; Beck, C.; Lecollinet, S.; Antalis, V.; Kalaitzopoulous, S.; Panagiotopoulos, T.; et al. Evaluation of a West Nile virus surveillance and early warning system in Greece, based on domestic pigeons. Comp. Immunol. Microbiol. Infect. Dis. 2014, 37, 131-141.

31. Höfle, U.; Gamino, V.; de Mera, I.G.; Mangold, A.J.; Ortíz, J.A.; de la Fuente, J. Usutu virus in migratory song thrushes, Spain. Emerg. Infect. Dis. 2013, 19, 1173-1175.

32. Buckley, A.; Dawson, A.; Gould, E.A. Detection of seroconversion to West Nile virus, Usutu virus and Sindbis virus in UK sentinel chickens. Virol. J. 2006, 3, e71.

33. Steinmetz, H.W.; Bakonyi, T.; Chvala, S.; Weissenböck, H.; Eulenberger, U.; Hatt, J.M.; Hoop, R.; Nowotny, N. Emergence of Usutu virus in Switzerland. In Proceedings of the 43rd International Symposium on Diseases of Zoo and Wild Animals, Edinburgh, UK, 16-20 May 2007; pp. 129-131.

34. Buchebner, N.; Zenker, W.; Wenker, C.; Steinmetz, H.W.; Sós, E.; Lussy, H.; Nowotny, N. Low Usutu virus seroprevalence in four zoological gardens in central Europe. BMC Vet. Res. 2013, 9, e153.

35. Nikolay, B.; Diallo, M.; Boye, C.S.; Sall, A.A. Usutu virus in Africa. Vector Borne Zoonotic Dis. 2011, 11, 1417-1423.

36. Chevalier, V.; Reynaud, P.; Lefrancois, T.; Durand, B.; Baillon, F.; Balanca, G.; Gaidet, N.; Mondet, B.; Lancelot, R. Predicting West Nile virus seroprevalence in wild birds in Senegal. Vector Borne Zoonotic Dis. 2009, 9, 589-596.

37. Ben Hassine, T.; de Massis, F.; Calistri, P.; Savini, G.; BelHaj Mohamed, B.; Ranen, A.; di Gennaro, A.; Sghaier, S.; Hammami, S. First detection of co-circulation of West Nile and Usutu viruses in equids in the south-west of Tunisia. Transbound. Emerg. Dis. 2014, 61, 385-389.

38. Manarolla, G.; Bakonyi, T.; Gallazzi, D.; Crosta, L.; Weissenböck, H.; Dorrestein, G.M.; Nowotny, N. Usutu virus in wild birds in northern Italy. Vet. Microbiol. 2010, 141, 159-163. 
39. Hubálek, Z.; Halouzka, J.; Juricová, Z.; Sikutová, S.; Rudolf, I.; Honza, M.; Janková, J.; Chytil, J.; Marec, F.; Sitko, J. Serologic survey of birds for West Nile flavivirus in southern Moravia (Czech Republic). Vector Borne Zoonotic Dis. 2008, 8, 659-666.

40. Figuerola, J.; Soriguer, R.; Rojo, G.; Gómez Tejedor, C.; Jimenez-Clavero, M.A. Seroconversion in wild birds and local circulation of West Nile virus, Spain. Emerg. Infect. Dis. 2007, 13, 1915-1917.

41. Hubálek, Z.; Wegner, E.; Halouzka, J.; Tryjanowski, P.; Jerzak, L.; Sikutová, S.; Rudolf, I.; Kruszewicz, A.G.; Jaworski, Z.; Wlodarczky, R. Serologic survey of potential vertebrate hosts for West Nile virus in Poland. Viral Immunol. 2008, 21, 247-253.

42. Linke, S.; Niedrig, M.; Kaiser, A.; Ellerbrok, H.; Müller, K.; Müller, T.; Conraths, F.J.; Mühle, R.U.; Schmidt, D.; Köppen, U.; et al. Serologic evidence of West Nile virus infections in wild birds captured in Germany. Am. J. Trop. Med. Hyg. 2007, 77, 358-364.

43. Lelli, R.; Savini, G.; Teodori, L.; Filipponi, G.; Di Gennaro, A.; Leone, A.; Gialleonardo, L.; Venturi, L.; Caporate, V. Serological evidence of Usutu virus occurrence in north-eastern Italy. Zoonoses Public Health 2008, 55, 361-367.

44. Hubálek, Z.; Rudolf, I.; Čapek, M.; Bakonyi, T.; Betášová, L.; Nowotny, N. Usutu virus in blackbirds (Turdus merula), Czech Republic, 2011-2012. Transbound. Emerg. Dis. 2014, 61, 273-276.

45. Vázquez, A.; Jiménez-Clavero, M.A.; Franco, L.; Donoso-Mantke, O.; Sambri, V.; Niedrig, M.; Zeller, H.; Tenorio, A. Usutu virus-potential risk of human disease in Europe. Euro. Surveill. 2011, 16, e19935.

46. Nikolay, B.; Dupressoir, A.; Firth, C.; Faye, O.; Boye, C.S.; Diallo, M.; Sall, A.A. Comparative full length genome sequence analysis of Usutu virus isolates from Africa. Virol. J. 2013, 10, e217.

47. Gaibani, P.; Cavrini, F.; Gould, E.A.; Rossini, G.; Pierro, A.; Landini, M.P.; Sambri, V. Comparative genomic and phylogenetic analysis of the first Usutu virus isolate from a human patient presenting with neurological symptoms. PLoS One 2013, 8, e64761.

48. Allering, L.; Jöst, H.; Emmerich, P.; Günther, S.; Lattwein, E.; Schmidt, M.; Seifried, E.; Sambri, V.; Hourfar, K.; Schmidt-Chanasit, J. Detection of Usutu virus infection in a healthy blood donor from south-west Germany, 2012. Euro. Surveill. 2012, 17, e20341.

49. Gaibani, P.; Pierro, A.; Alicino, R.; Rossini, G.; Cavrini, F.; Landini, M.P.; Sambri, V. Detection of Usutu virus-specific IgG in blood donors from northern Italy. Vector Borne Zoonotic Dis. 2012 , 12, 431-433.

50. Vilibic-Cavlek, T.; Kaic, B.; Barbic, L.; Pem-Novosel, I.; Slavic-Vrzic, V.; Lesniker, V.; Kurecic-Filipovic, S.; Babic-Erceg, A.; Listes, E.; Stevanovic, V.; et al. First evidence of simultaneous occurrence of West Nile virus and Usutu virus neuroinvasive disease in humans in Croatia during the 2013 outbreak. Infection 2014, 42, 689-695.

51. Bakonyi, T.; Lussy, H.; Weissenböck, H.; Hornyák, A.; Nowotny, N. In vitro host-cell susceptibility to Usutu virus. Emerg. Infect. Dis. 2005, 11, 298-301.

52. Suthar, M.S.; Brassil, M.M.; Blahnik, G.; McMillan, A.; Ramos, H.J.; Proll, S.C.; Belisle, S.E.; Katze, M.G.; Gale, M., Jr. A systems biology approach reveals that tissue tropism to West Nile virus is regulated by antiviral genes and innate immune cellular processes. PLoS Pathog. 2013, 9, e1003168. 
53. Weissenböck, H.; Bakonyi, T.; Chvala, S.; Nowotny, N. Experimental Usutu virus infection of suckling mice causes neuronal and glial cell apoptosis and demyelination. Acta Neuropathol. 2004, $108,453-460$.

54. Chvala, S.; Kolodziejek, J.; Nowotny, N.; Weissenböck, H. Pathology and viral distribution in fetal Usutu virus infection of birds from the 2001 and 2002 outbreaks in Austria. J. Comp. Pathol. 2004, $131,176-185$.

55. Brown, A.N.; Kent, K.A.; Bennett, C.J.; Bernard, K.A. Tissue tropism and neuroinvasion of West Nile virus do not differ for two mouse strains with different survival rates. Virology 2007, 368, $422-430$.

56. Orvedahl, A.; Levine, B. Viral evasion of autophagy. Autophagy 2008, 4, 280-285.

57. Khakpoor, A.; Panyasrivanit, M.; Wikan, N.; Smith, D.R. A role for autophagolysosomes in dengue virus 3 production in HepG2 cells. J. Gen. Virol. 2009, 90, 1093-1103.

58. Li, J.K.; Liang, J.J.; Liao, C.L.; Lin, Y.L. Autophagy is involved in the early step of Japanese encephalitis virus infection. Microbes Infect. 2012, 14, 159-168.

59. Blázquez, A.B.; Escribano-Romero, E.; Merino-Ramos, T.; Saiz, J.S.; Martín-Acebes, M.A. Infection with Usutu virus induces an autophagic response in mammalian cells. PLoS Negl. Trop. Dis. 2013, 7, e2509.

60. Miller, S.; Krijnse-Locker, J. Modification of intracellular membrane structures for virus replication. Nat. Rev. Microbiol. 2008, 6, 363-374.

61. Yu, C.Y.; Hsu, Y.W.; Liao, C.L.; Lin, Y.L. Flavivirus infection activates the XBP1 pathway of the unfolded protein response to facilitate replication and immune evasion. J. Virol. 2006, 80, 11868-11880.

62. Bakonyi, T.; Gould, E.A.; Kolodziejek, J.; Weissenböck, H.; Nowotny, N. Complete genome analysis and molecular characterization of Usutu virus that emerged in Austria in 2001: Comparison with the South African strain SAAR-1776 and other flaviviruses. Virology 2004, 328, 301-310.

63. Fulop, L.D.; Barrett, A.D.; Titball, R.W. Nucleotide sequence of the NS5 gene of Banzi virus: Comparison with other flaviviruses. J. Gen. Virol. 1995, 76, 2317-2321.

64. Gao, G.F.; Hussain, M.H.; Reid, H.W.; Gould, E.A. Classification of a new member of the TBE flavivirus subgroup by its immunological, pathogenetic and molecular characteristics: Identification of subgroup-specific pentapeptides. Virus Res. 1993, 30, 129-144.

65. Tamura, K.; Peterson, D.; Peterson, N.; Stecher, G.; Nei, M.; Kumar, S. MEGA5: Molecular evolutionary genetics analysis using maximum likelihood, evolutionary distance, and maximum parsimony methods. Mol. Biol. Evol. 2011, 28, 2731-2739.

66. Peletto, S.; lo Presti, A.; Modesto, P.; Cella, E.; Acutis, P.L.; Farchi, F.; Coitti, M.; Zehender, G.; Ciccozzi, M. Genetic diversity of Usutu virus. New Microbiol. 2012, 35, 167-174.

67. Solomon, T.; Dung, M.; Vaughn, D.W.; Kneen, R.; Thao, L.T.; Raengsakulrach, B.; Loan, H.T.; Day, N.P.; Farrar, J.; Myint, K.S. Neurological manifestations of dengue infection. Lancet 2000, $25,1053-1059$.

68. McMinn, P.C. The molecular basis of virulence of the encephalitogenic flaviviruses. J. Gen. Virol. 1997, 78, 2711-2722. 
69. Chu, J.J.; Rajamanonmani, R.; Bhuvanakantham, R.; Lescar, j.; Ng, M.L. Inhibition of West Nile virus entry by using a recombinant domain III from the envelope glycoprotein. J. Gen. Virol. 2005, $86,405-412$.

70. Chambers, T.J.; Halevy, M.; Nestorowicz, A.; Rice, C.M.; Lusting, S. West Nile virus envelope proteins: Nucleotide sequence analysis of strains differing in mouse neuroinvasiveness. J. Gen. Virol. 1998, 79, 2375-2380.

71. Liu, W.J.; Wang, X.J.; Mokhonov, V.V.; Shi, P.Y.; Randall, R.; Khromykh, A.A. Inhibition of interferon signaling by the New York 99 strain and Kunjin subtype of West Nile virus involves blockage of STAT1 and STAT2 activation by nonstructural proteins. J. Virol. 2005, 79, 1934-1942.

72. Beasley, D.W.; Barrett, A.D. Identification of neutralizing epitopes within structural domain III of the West Nile virus envelope protein. J. Virol. 2002, 76, 13097-13100.

73. Proutski, V.; Gould, E.A.; Holmes, E.C. Secondary structure of the $3^{\prime}$ untranslated region of flaviviruses: Similarities and differences. Nucleic Acids Res. 1997, 25, 1194-1202.

74. Shi, P.Y.; Li, W.; Brinton, M.A. Cell proteins bind specifically to West Nile virus minus-strand 3' stem-loop RNA. J. Virol. 1996, 70, 6278-6287.

75. Institut Pasteur de Dakar. Rapport Annuel. 1970.

76. Cavrini, F.; Della Pepa, M.E.; Gaibani, P.; Pierro, A.M.; Rossini, G.; Landini, M.P.; Sambri, V. A rapid and specific real-time RT-PCR assay to identify Usutu virus in human plasma, serum, and cerebrospinal fluid. J. Clin. Virol. 2011, 50, 221-223.

77. Nikolay, B.; Weidmann, M.; Dupressoir, A.; Faye, O.; Boye, C.S.; Diallo, M.; Sall, A.A. Development of a Usutu virus specific real-time reverse transcription PCR assay based on sequenced strains from Africa and Europe. J. Virol. Methods 2014, 197, 51-54.

78. Martin, D.A.; Noga, A.; Kosoy, O.; Johnson, A.J.; Petersen, L.R.; Lanciotti, R.S. Evaluation of a diagnostic algorithm using immunoglobulin M enzyme-linked immunosorbent assay to differentiate human West Nile virus and St. Louis encephalitis virus infections during the 2002 West Nile virus epidemic in the United States. Clin. Diagn. Lab. Immunol. 2004, 11, 1130-1133.

79. Solomon, T. Flavivirus encephalitis. N. Engl. J. Med. 2004, 351, 370-378.

80. Meister, T.; Lussy, H.; Bakonyi, T.; Sikutová, S.; Rudolf, I.; Vogl, W.; Winkler, H.; Frey, H.; Hubálek, Z.; Nowotny, N.; et al. Serological evidence of continuing high Usutu virus (Flaviviridae) activity and establishment of herd immunity in wild birds in Austria. Vet. Microbiol. 2008, 127, 237-248.

81. Brazil, M. Birds of East Asia: Eastern China, Taiwan, Korea, Japan, Eastern Russia; Christopher Helm: London, UK, 2009; p. 528.

82. Wang, G.; Li, C.; Guo, X.; Xing, D.; Dong, Y.; Wang, Z.; Zhang, Y.; Liu, M.; Zheng, Z.; Zhang, H.; et al. Identifying the main mosquito species in China based on DNA barcoding. PLoS One 2012, 7, e47051.

83. Knight, K.L.; Stone, A. A Catalog of the Mosquitoes of the World (Diptera: Culicidae), 2nd ed.; Thomas Say Foundation: Maryland, USA, 1977; Volume 6, pp. 1-610.

84. Kim, H.C.; Friendly, O.S.; Pike, J.G.; Schuster, A.L.; O’Guinn, M.L.; Klein, T.A. Seasonal prevalence of mosquito collected from light traps in the Republic of Korea, 2001. Korean J. Entomol. 2003, 33, 189-201. 
85. Lobigs, M.; Pavy, M.; Hall, R.A.; Lobigs, P.; Cooper, P.; Komiya, T.; Toriniwa, H.; Petrovsky, N. An inactivated Vero cell-grown Japanese encephalitis vaccine formulated with Advax, a novel inulin-based adjuvant, induces protecting neutralizing antibody against homologous and heterologous flaviviruses. J. Gen. Virol. 2010, 91, 1407-1417.

86. Petrovsky, N.; Larena, M.; Siddharthan, V.; Prow, N.A.; Hall, R.A.; Lobigs, M.; Morrey, J. An inactivated cell culture Japanese encephalitis vaccine (JE-ADVAX) formulated with delta inulin adjuvant provides robust heterologous protection against West Nile encephalitis via cross-protective memory B cells and neutralizing antibody. J. Virol. 2013, 87, 10324-10333.

87. Merino-Ramos, T.; Blázquez, A.B.; Escribano-Romero, E.; Cañas-Arranz, R.; Sobrino, F.; Saiz, J.C.; Martín-Acebes, M.A. Protection of a single dose West Nile virus recombinant subviral particle vaccine against linage 1 or 2 strains and analysis of the cross-reactivity with Usutu virus. PLoS One 2014, 9, e108056.

(C) 2015 by the authors; licensee MDPI, Basel, Switzerland. This article is an open access article distributed under the terms and conditions of the Creative Commons Attribution license (http://creativecommons.org/licenses/by/4.0/). 